\title{
Assessment of Consumer Property Quality of Enriched Bakery Products Using Classification Methods
}

\author{
Derkanosova N.M.* \\ Vice-Rector for Academic Affairs \\ Voronezh State Agrarian University named after the \\ Emperor Peter the Great \\ Voronezh, Russia \\ E-mail: kommerce05@list.ru
}

Ponomareva I.N.

Department of Commodity Science and Expertise of Goods

Voronezh State Agrarian University named after the

Emperor Peter the Great

Voronezh, Russia

E-mail: niirab@yandex.ru

\author{
Vasilenko O.A. \\ Department of Commodity Science and Expertise of Goods \\ Voronezh State Agrarian University named after the \\ Emperor Peter the Great \\ Voronezh, Russia \\ E-mail: ewa007@yandex.ru
}

\author{
Kalina M.A. \\ Voronezh State Agrarian University named after the \\ Emperor Peter the Great \\ Voronezh, Russia \\ E-mail: ewa007@yandex.ru
}

\author{
Shurshikova G.V. \\ Voronezh State University \\ Voronezh, Russia \\ E-mail: gshurshikova@list.ru
}

\begin{abstract}
The enrichment of food products with new raw ingredients, as a rule, faces the problem of changing their traditional characteristics. Accordingly, it is difficult to assume the attitude of consumers to these food products and to predict the success of their introduction to the consumer market. For an earlier assessment of new developments in the field of enriched (functional, specialized) bakery products, the use of classification methods is proposed. At the first stage, in relation to a specific product group - bread made from a mixture of rye and wheat flour, a scale of organoleptic evaluation with a characteristic of each quality level was developed. Graduation of bread from a mixture of rye and wheat flour was performed by expert evaluation procedure at the regional consumer market. For an objective classification of samples according to quality levels, a discriminant analysis was carried out, and linear discriminatory functions were obtained for the subsequent classification of new samples. Samples of grain triticale bread were expertly evaluated. It has been found, that despite the worse characteristics compared to Darnitsky bread, grain triticale bread produced through the developed technology is included in the "good" class, which suggests its positive entry into the consumer market.
\end{abstract}

Keywords - bakery products, triticale, consumer market, multivariate statistical analysis, classification methods.

\section{INTRODUCTION}

High-quality food products are the most important component of lifestyle, helping to maintain health and realize the reserve of longevity of the body. The discussed problem is especially relevant for consumer goods, which, of course, include bread. However, recently, due to the active introduction of accelerated and discrete technologies, the qualitative characteristics of bread began to undergo significant changes. This primarily relates to rye bread and bread from a mixture of rye and wheat flour. Traditional technologies based on the use of acid-forming semi-products form a characteristic sourish taste, fine and thin-walled porosity, taste and aroma determined by the products of lactic acid and alcoholic fermentation. The use of improvers leads to a decrease in acidity, increase in porosity, and change in the taste characteristics of bread. Besides, recently, new technologies have been actively introduced aimed at the production of "healthy" nutrition products, which include grain bread [1, 2].

\section{OBJECTS AND METHODS OF THE RESEARCH}

In connection with the foregoing, for an objective assessment of the bread quality, we proposed an improved scale of organoleptic indicators for bread made from rye and from a mixture of rye and wheat flour (table 1) [3].

The procedure was tested with the purpose of grading bread from a mixture of rye and wheat flour sold in retail networks, and was also used to determine to which one of the classification groups the new types of products belong [4]. 
TABLE I. SCALE OF ORGANOLEPTIC ASSESSMENT OF THE BREAD MADE FROM A MIXTURE OF RYE AND WHEAT FLOUR

\begin{tabular}{|c|c|c|c|}
\hline Quality indicator & $\begin{array}{c}\text { Weight } \\
\text { coefficient* }\end{array}$ & $\begin{array}{c}\text { Numerical value of the quality } \\
\text { levels }\end{array}$ & Quality level description \\
\hline 1 & 2 & 3 & 4 \\
\hline \multirow[t]{5}{*}{$\begin{array}{l}\text { Appearance (shape, } \\
\text { surface) }\end{array}$} & \multirow[t]{5}{*}{2.5} & 5 & $\begin{array}{l}\text { Regular shape (not crumpled, not misshapen, without side burls). Surface } \\
\text { is smooth and sleek. Shape of hearth bread is round or oval, regular, } \\
\text { surface is a little rough }\end{array}$ \\
\hline & & 4 & $\begin{array}{l}\text { Quite regular shape, fitting the type of product. Surface is smooth and } \\
\text { quite sleek. For hearth bread - rough }\end{array}$ \\
\hline & & 3 & $\begin{array}{l}\text { The shape is a little irregular or bound, surface is smooth with small } \\
\text { cracks, quite sleek, somewhat floury, rough }\end{array}$ \\
\hline & & 2 & $\begin{array}{l}\text { Irregular shape, misshapen or bound. Surface with cracks, not sleek, } \\
\text { floury, rough }\end{array}$ \\
\hline & & 1 & $\begin{array}{l}\text { Irregular shape, misshapen or bound, crumpled, with side burls, not } \\
\text { fitting the product type. Surface with cracks and tears, not sleek, } \\
\text { considerably floury, rough }\end{array}$ \\
\hline \multirow{5}{*}{ Crust color } & \multirow[t]{5}{*}{1.5} & 5 & Even, from light-brown to brown \\
\hline & & 4 & Quite even, from light-cream to dark-brown \\
\hline & & 3 & Not very even, cream or dark-brown \\
\hline & & 2 & Uneven, pale, dark-brown, dirty \\
\hline & & 1 & Slightly burnt, too pale, dirty \\
\hline \multirow{5}{*}{$\begin{array}{l}\text { Porosity } \\
\text { characteristics }\end{array}$} & \multirow[t]{5}{*}{2.0} & 5 & Even, fine-porous, thin-walled. \\
\hline & & 4 & Quite even, fine-porous \\
\hline & & 3 & Not very even, various pore size \\
\hline & & 2 & Very fine, poor. Large, thick-walled, with cavities \\
\hline & & 1 & Considerable number of contractions, cavities, undermixing \\
\hline \multirow{5}{*}{$\begin{array}{l}\text { Physical and } \\
\text { mechanical properties } \\
\text { of the crumb }\end{array}$} & \multirow[t]{5}{*}{3.0} & 5 & Very soft, tender, elastic \\
\hline & & 4 & Soft, elastic \\
\hline & & 3 & Quite soft, somewhat crippling \\
\hline & & 2 & Contracted, little elastic, crippling \\
\hline & & 1 & Contracted, not elastic, sticky \\
\hline \multirow{5}{*}{$\begin{array}{l}\text { Crumb color } \\
\text { (depending on the } \\
\text { proportion of rye and } \\
\text { wheat flour) }\end{array}$} & \multirow[t]{5}{*}{1.5} & 5 & From cream to light brown, evenly colored \\
\hline & & 4 & Light-cream, brown, quite evenly colored \\
\hline & & 3 & Quite light, greyish, brown, unevenly colored \\
\hline & & 2 & Grey, dark-brown, unevenly colored \\
\hline & & 1 & Dark-brown, light-grey or yellowish, typical for wheat bread, uneven \\
\hline \multirow[t]{5}{*}{ Aroma } & \multirow[t]{5}{*}{3.5} & 5 & $\begin{array}{l}\text { Aroma typical for bread from a mixture of rye and wheat flour (of lactic } \\
\text { acid and alcoholic fermentation products), strong }\end{array}$ \\
\hline & & 4 & Attractive, typical for bread from a mixture of rye and wheat flour, strong \\
\hline & & 3 & Sourish, weak \\
\hline & & 2 & Sour, yeasty, empty, unmarked \\
\hline & & 1 & Stale, foreign \\
\hline \multirow[t]{5}{*}{ Taste } & \multirow[t]{5}{*}{4.0} & 5 & $\begin{array}{l}\text { Pleasant, typical for bread from a mixture of rye and wheat flour (soft, } \\
\text { sourish), strong }\end{array}$ \\
\hline & & 4 & Pleasant, typical for the product, sourish, strong \\
\hline & & 3 & Sour, brakish, somewhat flavorless \\
\hline & & 2 & Sour, yeasty, flavorless, saline \\
\hline & & 1 & Not typical for the product, foreign flavor \\
\hline \multirow[t]{5}{*}{ Chewability } & \multirow[t]{5}{*}{2.0} & 5 & Well chewed, very tender sensations, not clogging \\
\hline & & 4 & Well chewed, slightly clogging \\
\hline & & 3 & Clogging, somewhat coarse, crumbling \\
\hline & & 2 & Considerably clogging, coarse, crumbling \\
\hline & & 1 & Very clogging, very crumbling \\
\hline
\end{tabular}

a. * for comprehensive assessment of the bread quality, a 100-point scale is used, which, with a 5-level assessment of individual quality indicators, provides for the introduction of weighting factors, the sum of which is

During the tasting, the expert commission included representatives of the supervision and control bodies, and the expert communities in the field of bakery products. 17 encrypted bread samples from a mixture of rye and wheat flour, selected in the trade organizations were presented for the tasting.

\section{RESEARCH RESULTS}

The obtained values of individual quality indicators were statistically processed, presented in the form of complex characteristics and expertly grouped by conventional quality levels (table 2). The indicators are interpreted as follows: $x 1-$ appearance (shape, surface); x 2 - crust color; x 3 - porosity characteristics (size and evenness of pores, wall thickness); $\mathrm{x} 4$ - physical and mechanical properties of the crumb (crumb resistance to finger pressure); $\mathrm{x} 5$ - crumb color (depending on the proportion of rye and wheat flour); $\mathrm{x} 6$ - aroma; $\mathrm{x} 7$ - taste; $\mathrm{x} 8$ - chewability. 
TABLE II. INFORMATION ON THE QUALITY OF BREAD FROM A MIXTURE OF RYE AND WHEAT FLOUR IN RETAIL NETWORKS (BASED ON THE DATA FROM THE INDEPENDENT EXPERT ASSESSMENT)

\begin{tabular}{|c|c|c|c|c|c|c|c|c|c|}
\hline$\#$ & Sample & $x_{1}$ & $x_{2}$ & $x_{3}$ & $x_{4}$ & $x_{5}$ & $x_{6}$ & $x_{7}$ & $x_{8}$ \\
\hline \multicolumn{8}{|c|}{ Product group 1 - "good" } \\
\hline 1 & 1 & 9 & 7.3 & 8.3 & 14.0 & 6.8 & 17.5 & 18.7 & 8.0 \\
\hline 2 & 4 & 9 & 6.3 & 10.0 & 13.5 & 6.5 & 15.2 & 15.3 & 9.0 \\
\hline 3 & 5 & 8.3 & 6.5 & 9.6 & 12.5 & 6.8 & 14.6 & 16.0 & 8.7 \\
\hline 4 & 6 & 7.7 & 6.3 & 10.8 & 12.5 & 6.3 & 15.8 & 16.0 & 8.7 \\
\hline 5 & 7 & 8.7 & 7.0 & 8.8 & 12.5 & 7.0 & 14.6 & 16.0 & 8.3 \\
\hline 6 & 8 & 9.7 & 7.3 & 10.4 & 13.5 & 7.0 & 15.3 & 18.7 & 9.0 \\
\hline 7 & 10 & 8.3 & 6.5 & 9.2 & 12.0 & 6.3 & 14.6 & 15.3 & 8.3 \\
\hline 8 & 11 & 8.7 & 6.3 & 10.8 & 12.5 & 6.5 & 15.2 & 15.3 & 7.7 \\
\hline 9 & 13 & 8.7 & 6.3 & 11.7 & 14.5 & 7.3 & 16.3 & 18.7 & 9.0 \\
\hline 10 & 14 & 8.0 & 6.8 & 10.4 & 12.0 & 6.5 & 15.8 & 17.3 & 9.0 \\
\hline 11 & 15 & 9.3 & 6.8 & 11.7 & 13.5 & 7.0 & 15.8 & 18.0 & 9.3 \\
\hline \multicolumn{8}{|c|}{ Product group $2-$ "bad" } \\
\hline 12 & 2 & 7.3 & 6.5 & 6.7 & 13.5 & 6.5 & 14.6 & 16.7 & 8.0 \\
\hline 13 & 3 & 7.7 & 5.8 & 5.8 & 11.0 & 4.8 & 9.9 & 10.7 & 8.3 \\
\hline 14 & 9 & 8.0 & 5.8 & 7.1 & 12.0 & 5.0 & 14.0 & 15.3 & 7.7 \\
\hline 15 & 16 & 8.0 & 6.3 & 8.8 & 12.0 & 6.0 & 13.4 & 12.7 & 7.7 \\
\hline 16 & 17 & 6.7 & 4.8 & 7.1 & 10.5 & 4.8 & 10.5 & 11.3 & 7.0 \\
\hline 17 & 18 & 7.3 & 5.3 & 8.8 & 11.5 & 5.5 & 11.1 & 12.7 & 6.3 \\
\hline \multicolumn{10}{|c|}{} \\
\hline 8
\end{tabular}

For an objective classification of samples according to quality levels, a discriminant analysis was carried out, the purpose of which is to obtain linear discriminatory functions for the subsequent classification of new samples. Previously, the values of the indicators are normalized by the formula: where $i$ is the indicator number, $j$ is the sample number, in the numerator there is the primary value, in the denominator it is the average value of the indicator.

The results of normalization are demonstrated in table 3, where, according to the preliminary classification, class 1 refers to the product group "good" and class 2 - product group "bad".

TABLE III. NORMALIZED INDICATORS

\begin{tabular}{|c|c|c|c|c|c|c|c|c|c|c|}
\hline 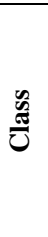 & 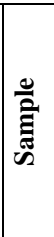 & $x_{1}$ & $x_{2}$ & $x_{3}$ & $x_{4}$ & $x_{5}$ & $x_{6}$ & $x_{7}$ & $x_{8}$ & 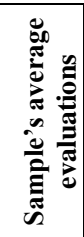 \\
\hline 1 & 1 & 1.090 & 1.150 & 0.904 & 1.115 & 1.084 & 1.218 & 1.201 & 0.971 & \begin{tabular}{|l|}
1.092 \\
\end{tabular} \\
\hline 1 & 4 & 1.090 & 0.993 & 1.090 & 1.075 & 1.037 & 1.058 & 0.983 & 1.093 & 1.052 \\
\hline 1 & 5 & 1.005 & 1.024 & 1.046 & 0.995 & 1.084 & 1.016 & 1.028 & 1.056 & 1.032 \\
\hline 1 & 6 & 0.932 & 0.993 & \begin{tabular}{|l|l|}
1.177 \\
\end{tabular} & 0.995 & 1.005 & 1.100 & 1.028 & 1.056 & 1.036 \\
\hline 1 & 7 & 1.053 & 1.103 & 0.959 & 0.995 & 1.116 & 1.016 & 1.028 & 1.008 & 1.035 \\
\hline 1 & 8 & 1.175 & 1.150 & 1.133 & 1.075 & 1.116 & 1.065 & 1.201 & 1.093 & 1.126 \\
\hline 1 & 10 & 1.005 & 1.024 & 1.003 & 0.956 & 1.005 & 1.016 & 0.983 & 1.008 & 1.000 \\
\hline 1 & 11 & 1.053 & 0.993 & \begin{tabular}{|l|}
1.177 \\
\end{tabular} & 0.995 & 1.037 & 1.058 & 0.983 & 0.935 & 1.029 \\
\hline 1 & 13 & 1.053 & 0.993 & 1.275 & 1.155 & 1.164 & 1.135 & 1.201 & 1.093 & 1.134 \\
\hline 1 & 14 & 0.969 & 1.071 & 1.133 & 0.956 & 1.037 & 1.100 & 1.111 & 1.093 & 1.059 \\
\hline 1 & 15 & 1.126 & 1.071 & 1.275 & 1.075 & 1.116 & 1.100 & 1.156 & 1.129 & 1.131 \\
\hline 2 & 2 & 0.884 & 1.024 & 0.730 & 1.075 & 1.037 & 1.016 & 1.073 & 0.971 & 0.976 \\
\hline 2 & 3 & 0.932 & 0.914 & 0.632 & 0.876 & 0.765 & 0.689 & 0.687 & 1.008 & 0.813 \\
\hline 2 & 9 & 0.969 & 0.914 & 0.774 & 0.956 & 0.797 & 0.975 & 0.983 & 0.935 & 0.913 \\
\hline 2 & 16 & 0.969 & 0.993 & 0.959 & 0.956 & 0.957 & 0.933 & 0.816 & 0.935 & 0.940 \\
\hline 2 & 17 & 0.811 & 0.756 & 0.774 & 0.836 & 0.765 & 0.731 & 0.726 & 0.850 & \begin{tabular}{|l|}
0.781 \\
\end{tabular} \\
\hline 2 & 18 & 0.884 & 0.835 & 0.959 & 0.916 & 0.877 & 0.773 & 0.816 & 0.765 & 0.853 \\
\hline
\end{tabular}

The division into two classes performed using STATISTICA 6.0 and the method of K-averages demonstrates that the results fit the preliminary classification into groups "good - cluster 1" and "bad - cluster 2".

Based on the data of table 3 the discriminant analysis was performed $[4,5]$.

To analyze the statistics of variables included in the model, the Wilks lambda, Private lambda, and squares of the Mahalanobis distance calculated in the STATISTICA system were used. Wilks lambda takes values in the range from 0 to 1 and serves to check the quality of discrimination. Moreover, the closer the value to zero is, the less probable is the erroneous separation. The statistic value of 1 indicates a "poor" quality of the model. The Wilks lambda values for each variable are the result of the exclusion of the corresponding indicator from the model, the larger the value, the more desirable the presence of this indicator in the discrimination procedure. The value "Particular lambda" is the ratio of the Wilks lambda after adding the corresponding indicator to the model to the Wilks lambda without this indicator. The Particular lambda characterizes the single contribution of the corresponding indicator to the dividing power of the model: the smaller the value of "Particular lambda", the greater the contribution of the indicator to general discrimination.

The posterior probability shows the probable belonging of a particular observation to any class calculated on the basis of the distance of Mahalanobis and allows assessing the quality of discrimination $[4,5]$.

The analysis of the results made it possible to determine that individual quality indicators, indicators $\mathrm{x} 3$ and $\mathrm{x} 7$, make a minimal contribution to discrimination. In fact, the third (porosity characteristics) and seventh (taste) criteria are identification for classifying bread as a group of products from a mixture of rye and wheat flour. Sampling for analysis was carried out from this group, provided that they fully met the requirements of the current regulatory documentation, including organoleptic indicators. In this connection, with a sufficiently high significance of these criteria from the standpoint of evaluating the consumer properties of bread, we can agree with minimizing their influence in the classification of products according to quality levels. Fig. 1 shows the values of the coefficients of the variables (indicators) of the model, Fig. 2 shows the main statistics, and Fig. 3 shows posterior probabilities indicating that all observations are correctly classified.

As a result, the presented data allow writing down the classification functions for each group of observations as follows:

Group 1:

$$
\begin{aligned}
& D 1=-230,322+223,334 x_{1}-94,089 x_{2}-168,109 x_{4}+ \\
& +182,962 x_{5}+112,832 x_{6}+171,630 x_{8}
\end{aligned}
$$

Group 2:

$$
\begin{aligned}
& D 2=-157,621+142,381 x_{1}-22,769 x_{2}-16,826 x_{4}+ \\
& +82,474 x_{5}+34,698 x_{6}+130,882 x_{8}
\end{aligned}
$$




\begin{tabular}{|l|c|c|}
\hline \multirow{2}{*}{ Variable } & \multicolumn{3}{|c|}{ Classification functions; grouping Var9 (data table) } \\
\cline { 2 - 3 } & $\begin{array}{c}\text { G } 1: 1 \\
p=64706\end{array}$ & $\begin{array}{c}\text { G } 2: 2 \\
p=, 64706\end{array}$ \\
\hline Var1 & 223.344 & 142,381 \\
\hline Var2 & -94.089 & $-22,769$ \\
\hline Vart & -168.109 & $-16,826$ \\
\hline Var5 & 182.962 & 82,474 \\
\hline Var6 & 112.832 & 34,474 \\
\hline Var8 & 171.630 & 130,862 \\
\hline Constant & $-230,332$ & $-157,621$ \\
\hline
\end{tabular}

Fig. 1. STATISTICA system window "Classification functions"

\begin{tabular}{|l|c|c|}
\hline \multirow{2}{*}{ Variable } & \multicolumn{3}{|c|}{ Classification functions; grouping Var9 (data table) } \\
\cline { 2 - 3 } & $\begin{array}{c}\text { G_ } 1: 1 \\
\mathrm{p}=, 64706\end{array}$ & $\begin{array}{c}\text { G_ } 2: 2 \\
\mathrm{p}=, 64706\end{array}$ \\
\hline Var1 & 223.344 & 142,381 \\
\hline Var2 & .94 .089 & $-22,769$ \\
\hline Vart & -168.109 & $-16,826$ \\
\hline Var5 & 182.962 & 82,474 \\
\hline Var6 & 112.832 & 34,474 \\
\hline Var8 & 171.630 & 130,862 \\
\hline Constann & $-230,332$ & $-157,621$ \\
\hline
\end{tabular}

Fig. 2. STATISTICA system window "Posterior probabilities"

\begin{tabular}{|c|c|c|c|c|c|c|}
\hline \multirow[b]{2}{*}{$N=17$} & \multicolumn{6}{|c|}{ 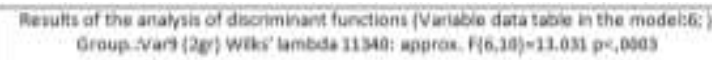 } \\
\hline & $\begin{array}{l}\text { Wikg } \\
\text { lanbida }\end{array}$ & $\begin{array}{l}\text { Bivate } \\
\text { ambda }\end{array}$ & $\begin{array}{c}\text { F. an } \\
\text { excepton } \\
(1,10)\end{array}$ & P. wov & Toler. & $\begin{array}{l}\text { 1.toler: } \\
\text { [R.kv] }\end{array}$ \\
\hline ven & 0.191160 & 0.62543 & 5,97568 & 0,034576 & 0.432200 & 0,567732 \\
\hline $\operatorname{ven} 2$ & 0.154359 & 0,734023 & 3,01231 & 0,080536 & 0,300432 & 0,09450 \\
\hline Vard & 0.245305 & 0,402159 & 11.637 & 0,020612 & 0.153001 & $0, a 46 a 19$ \\
\hline Vars & 0,219994 & 0.515432 & 9,46040 & 0,011922 & 0.27271 & 0,727219 \\
\hline vero & 0.295350 & 0.552198 & 8,1057 & 0.02776 & 0.202020 & 0,717369 \\
\hline ves & 0140394 & 0.807698 & 2,30567 & 0.133159 & 0,779428 & 0,220513 \\
\hline
\end{tabular}

Fig. 3. STATISTICA system window "Analysis of discriminant functions"

It should be noted that the performed transformations did not change the expert gradation (Table 2), as well as the division into classes according to the results of normalizing the indicator values, which confirmed the hypothesis put forward earlier on the gradation of bakery products according to organoleptic indicators.

The obtained classification functions allow assessing the belonging of a new product to one of the groups and, accordingly, assuming its place in the current market. The analyzed sample will be assigned to the group for which the value of the discriminatory function will be greater.

We use the obtained laws to classify the new development, grain triticale bread to some group in terms of quality. The use of non-traditional raw ingredients allows of variation of the nutritional value of the finished product and (or) giving the products certain functional or specialized properties [6-11].
Accelerated technology for grain bread production includes the following stages:

- preparation of grain for production;

- grinding the grain mass;

- kneading the dough;

- dough maturing;

- cutting dough pieces;

- proofing of dough pieces;

- bread baking.

The technology uses pre-purified and washed grain free from mineral and organic impurities. Grain preparation in the conditions of baking production involves steeping. Steeping duration for triticale grain using ferment preparation Pentopan $500 \mathrm{BG}$ with activity of 2700 items/g and dosage of $0.004 \%$ of the grain weight with $\mathrm{pH} 4.8$ and temperature $40{ }^{\circ} \mathrm{C}$ is 12 hours up to the moisture content of $45 \%$. To prepare the dough, the remaining ingredients according to the recipe (pressed baking yeast, edible salt, white sugar, refined vegetable oil, acidifiers) are added to the grain crushed on a disperser to a particle size of not more than $0.5 \mathrm{~mm}$ and mixed for 7-10 minutes. Dry gluten is added last. After kneading, the dough is left for maturing for 30-40 minutes at room temperature to relieve internal stresses that have arisen inside the grain mass during grinding and kneading of the dough. Then, proofing is carried out for 45-55 minutes and then dough pieces are baked at a temperature of 210-220 ${ }^{\circ} \mathrm{C}$ for $30-32$ minutes $[12,13]$.

Samples prepared according to the designed technology have the characteristics close to traditional types of bread from a mixture of rye and wheat flour, but not identical to the latter. They are described by crump moisture content of $46.9 \pm 0.2 \%$, titratable acidity $8.1 \pm 0.2$ degrees, porosity $61.2 \pm 1.0 \%$, specific volume $185.5 \pm 4.0 \mathrm{~cm}^{3} / 100 \mathrm{~g}$. They have pretty good value of aroma-forming matters (table 4 ).

TABLE IV. CONTENT OF AROMA-FORMING MATTERS IN THE BREAD

\begin{tabular}{|l|c|}
\hline \multicolumn{1}{|c|}{ Sample } & $\begin{array}{c}\text { Aldehyde concentration in equivalent of } \\
\mathbf{c m}^{\mathbf{3}} \text { of iodine solution of } \mathbf{0 , 1 m o l e} / \mathbf{c m}^{\mathbf{3}}\end{array}$ \\
\hline Grain bread & $28.2 \pm 0.2$ \\
\hline $\begin{array}{l}\text { Bread from a mixture of rye } \\
\text { and wheat flour (Darnitskiy) }\end{array}$ & $27.6 \pm 0.2$ \\
\hline
\end{tabular}

It is traditionally believed that cooking bread in an accelerated way, without the fermentation stage, negatively affects the aroma, it becomes less pronounced. However, the obtained results showed that bread produced using accelerated technology (grain bread) is not inferior to the content of aldehydes compared to the bread baked using the traditional technology. The content of aldehydes in the Darnitskiy pan bread is approximately equal to their content in experimental bread samples produced using the accelerated technology.

At the same time, the main development goal is achieved increasing the nutritional value of the finished product (table 5). Ordinary rye-wheat bread was taken as a comparison sample, as the closest one from the standpoint of maximum use of grain potential. 
TABLE V. NUTRIENT CONCENTRATION IN 100 G OF BREAD

\begin{tabular}{|l|c|c|}
\hline Nutrient & Ordinary ryewheat bread & Grain bread \\
\hline Mass fraction of moisture, $\mathrm{g}$ & $46.9 \pm 0.2$ & $46.9 \pm 0.2$ \\
\hline Mass fraction of protein, $\mathrm{g}$ & $7.0 \pm 0.1$ & $10.3 \pm 0.2$ \\
\hline Mass fraction of fat, $\mathrm{g}$ & $1.12 \pm 0.03$ & $2.73 \pm 0.08$ \\
\hline $\begin{array}{l}\text { Mass fraction of } \\
\text { carbohydrates, } \mathrm{g}\end{array}$ & $40.3 \pm 1.0$ & $35.0 \pm 1.0$ \\
\hline Gluten, g & $1.09 \pm 0.03$ & $1.71 \pm 0.03$ \\
\hline Ash, g & $2.50 \pm 0.06$ & $2.71 \pm 0.07$ \\
\hline Minerals, mg & $589 \pm 16$ & $431 \pm 14$ \\
\hline Sodium & $195 \pm 6$ & $310 \pm 8$ \\
\hline Potassium & $37 \pm 1$ & $42 \pm 1$ \\
\hline Calcium & $55 \pm 2$ & $93 \pm 2$ \\
\hline Magnesium & $178 \pm 6$ & $117 \pm 4$ \\
\hline Phosphorus & $2.70 \pm 0.08$ & $2.91 \pm 0.08$ \\
\hline Iron & $0.190 \pm 0.06$ & $0.230 \pm 0.07$ \\
\hline Vitamins, $\mathrm{mg}$ & $0.110 \pm 0.002$ & $0.110 \pm 0.002$ \\
\hline Thiamine $\left(\mathrm{B}_{1}\right)$ & $1.46 \pm 0.04$ & $1.51 \pm 0.04$ \\
\hline Riboflavin $\left(\mathrm{B}_{2}\right)$ & 199.1 & 205.4 \\
\hline Niacin PP & & \\
\hline Energy value, kcal & & \\
\cline { 1 - 2 } & & \\
\hline
\end{tabular}

To assess the nutritional value of grain triticale bread, the degree of sufficiency of nutrients was determined in accordance with the "Norms of the physiological need for energy and nutrients for various groups of the population of the Russian Federation" (MP 2.3.1.2432-08). The calculations were carried out for men, for protein - for men of the III group of physical activity aged 30 to 39 years. The studies have shown that $250 \mathrm{~g}$ of grain triticale bread satisfied $21.3 \%$ of the daily requirement for dietary fiber, $57.2 \%$ - of vegetable protein, $58.1 \%$ - magnesium, $36.5 \%$ - phosphorus, $72.7 \%$ iron, $38.3 \%$ - thiamine. According to GOST 52349-2005. "Food products. Functional food products. Terms and definitions", it allows considering grain triticale bread as functional food product.

However, despite the obvious benefits of grain bread from the standpoint of enriching nutrition with physiologically necessary nutrients, it is difficult to expect from such finished products consumer perception of their organoleptic properties similar to the traditional ones.

To assess the level of consumer properties of grain products, laboratory baking was carried out, and expertly evaluated samples of grain triticale bread produced by traditional technology with thick sourdough (sample 1) and accelerated technology (sample 2).

The comparative assessment of the quality indicators of bread is shown in table 6 .

TABLE VI. INFORMATION ON THE QUALITY OF GRAIN TRITICALE BREAD (BASED ON THE DATA FROM THE INDEPENDENT EXPERT ASSESSMENT)

\begin{tabular}{|c|c|c|c|c|c|c|c|c|c|}
\hline 冚㐫 & $x_{1}$ & $x_{2}$ & $x_{3}$ & $x_{4}$ & $x_{5}$ & $x_{6}$ & $x_{7}$ & $x_{8}$ & 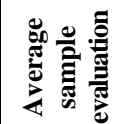 \\
\hline 1 & 10.0 & 6.9 & 9.4 & 14.1 & 6.8 & 16.1 & 19.0 & 9.0 & 11.413 \\
\hline 2 & 9.5 & 6.9 & 8.0 & 12.6 & 6.0 & 13.6 & 16.0 & 8.0 & 10.075 \\
\hline \multicolumn{10}{|c|}{ Normalized values } \\
\hline 1 & 1.188 & 1.077 & 1.030 & 1.115 & 1.082 & 1.117 & 1.205 & 1.089 & 1.113 \\
\hline 2 & 1.129 & 1.077 & 0.877 & 0.997 & 0.955 & 0.943 & 1.014 & 0.968 & 0.995 \\
\hline
\end{tabular}

The classification results presented in table 5 and the values of the discriminant functions calculated according to equations 1-2 (table 7) allow drawing an unambiguous conclusion about the belonging of the samples to the "good" class.

TABLE VII. THE VALUES OF DISCRIMINANT FUNCTIONS

\begin{tabular}{|c|c|c|c|}
\hline \multirow{2}{*}{ Sample number } & \multicolumn{2}{|c|}{ The values of discriminant functions } & \multirow{2}{*}{ Class } \\
\cline { 2 - 3 } & D1 & D2 & \\
\hline 1 & 257.129 & 238.816 & "good" \\
\hline 2 & 200.177 & 199.998 & "good" \\
\hline
\end{tabular}

Bread produced by the traditional technology has the best calculated characteristics, which coincides with the opinion of experts. However, the use of thick sourdough significantly reduces the proportion of triticale grains in the finished product, which contradicts the goal set in the work - enrichment of bakery products with functional food ingredients. Despite the comparatively worse characteristics, grain bread produced using the accelerated technology is included in the "good" class, which suggests its positive entry into the consumer market.

\section{SUMMARY}

Thus, the adaptation of the methods of multivariate statistical data analysis made it possible to confirm the feasibility of grain triticale bread technology based on determining the belonging of finished products to the best group of products in the regional consumer market.

\section{References}

[1] G.Ts. Tsybikova, E.G. Ineshina, D.N. Khamkhanova, "Improving the technology for the production of whole-grain bread", Technique and technol. of food product., vol. 4, pp. 64a-67, 2010.

[2] E.A. Kuznetsova, Development of scientific foundations and ways to improve the safety of grain raw materials in the technology of bakery products. Orel, 2017.

[3] M.A. Kalina, Development of grain bread and assessment of its consumer properties. Moscow, 2012

[4] V.V. Davnis, V.I. Tinyakova, Predictive models of expert preferences. Voronezh, 2005.

[5] A.A. Khalafanyan, Statistica 6, Statistical Data Analysis, 3rd ed Moscow: Binom-Press, 2008.

[6] I.M. Zharkova, A.A. Zvyagin, L.A. Miroshnichenko et al., "Gluten-free diet optimization with new products", Vopr. pitaniya, vol. 17, pp. 59-65, 2017.

[7] I.A. Bavykina, A.A. Zvyagin, I.M. Zharkova et al., "The effectiveness of amaranth products in gluten-free nutrition for children with gluten intolerance", Vopr. pitaniya, vol. 86, pp. 91-99, 2017.

[8] I.M. Zharkova, Scientific and practical substantiation and development of technologies for specialized flour products. Krasnodar, 2017

[9] M.S. Gins, V.K. Gins, V.F. Pivovarov et al., Functional foods from amaranth seeds and leaves. Moscow:VNIISSOK, 2015

[10] M.S. Gins, V.F. Pivovarov, V.K. Gins et al., "Scientific support of innovative technologies in the creation of functional products based on vegetable crops", Ovoŝi Rossii, vol. 1, no. 2), pp. 4-9, 2014.

[11] N.A. Derkanosova, S.A. Shelamova, V.I. Manzhesov et al., Enriched Foods: Developing Consumer Properties, Aa collective monograph. Voronezh: FGBOU VPO Voronezhskiy GAU, 2015.

[12] S.Ya. Koryachkina, E.A. Kuznetsova, "The use of enzyme preparation of cytolytic action in the production of whole grain bread", Food Technol., vol. 4, pp. 25-27, 2003.

[13] S.Ya. Koryachkina, E.A. Khmeleva, E.N. Kuznetsova, M.A. Kalina, "The study of the process of soaking wheat grain in the production of grain bread", Khleboproducty, vol. 7, pp. 43-45, 2010. 